\title{
Alloy Designation, Processing, and Use of AA6XXX Series Aluminium Alloys
}

\author{
Prantik Mukhopadhyay \\ Electron Microscope Group, Defence Metallurgical Research Laboratory, Kanchanbagh, Hyderabad 500058, India \\ Correspondence should be addressed to Prantik Mukhopadhyay, prantikmukherje@yahoo.com
}

Received 1 February 2012; Accepted 23 February 2012

Academic Editors: R. Hebert and Y. Yamabe-Mitarai

Copyright ( $) 2012$ Prantik Mukhopadhyay. This is an open access article distributed under the Creative Commons Attribution License, which permits unrestricted use, distribution, and reproduction in any medium, provided the original work is properly cited.

\begin{abstract}
The strength-to-weight ratio offered by AA6XXX alloys and their enhanced mechanical properties have become crucial criteria for their use in light weight military vehicles, rockets, missiles, aircrafts, and cars, used for both defence and civil purpose. The focus of this review paper is to put together the latest knowledge available from various sources on alloy design, industrial processing, development of properties, and potential use of AA6XXX alloys. The direct chill (DC) cast AA6XXX wrought alloys which are subsequently processed by fabrication process like hot working, cold working, process annealing, and age hardening heat treatments are the foci of this review though designation section also contains the designations of cast alloys to provide the reader a broad overview on designation. World-wide accepted designations are briefly tabled along with their alloying elements. The effects of the alloying elements which are generally used for AA6XXX wrought alloys are discussed incorporating their interactions during wrought AA6XXX alloy fabrication. The significance of the alloying and also the processing to develop the certain properties and the underlying strengthening mechanisms are discussed. The frequent and versatile uses of these AA6XXX alloys for the structural applications both in defence and civil purpose are put forth.
\end{abstract}

\section{Introduction}

The properties of AA6XXX wrought alloys like high strengthto-weight ratio, plasticity, capacity for crucial shape forming along with their ease for joining and good corrosion resistance have become increasingly focused for versatile applications such as design of armour structures, rocket, missile casing, light-weight defence vehicle, cars, and marine structures [1-5]. Varieties of AA6XXX wrought alloys have been developed by manipulating their compositions and tailoring the fabrication technology for the above-mentioned applications [2-10]. The requirements for producing high-quality AA6XXX wrought alloys are inevitably associated with precision alloy design, innovative technology development in processing and enhancement of mechanical properties $[1,2]$. The genesis of these upgraded Taylor-made properties demands the knowledge of underlying mechanisms which govern the strengthening phenomenon [3-10]. The focus of this review paper is to put together the latest knowledge available from various sources on alloy designation, industrial processing, development of properties, and potential use of AA6XXX wrought alloys.

\section{Designation}

Aluminium offers weight saving because of its light weight. The softness of this metal can restrict its use for the engineering purposes. Hence, the strengthening of this metal is required for its use in cars, light-weight armour vehicles, rockets, missiles, and aircraft structures in civil and defence sectors, which demand high strength-to-weight ratio. The strengthening of $\mathrm{Al}$ is principally done by alloying it with elements like $\mathrm{Cu}, \mathrm{Zn}, \mathrm{Mn}, \mathrm{Mg}, \mathrm{Si}$, and $\mathrm{Li}$ and processing its alloys. Generally, a four-digit numerical designation is used to specify aluminium and its alloys (Table 1), where first digit denotes the principal alloying element except AA1XXX series, which stands for purity of aluminium. The second digit stands for the changes to impurity limits. The minimum $\% \mathrm{Al}$ (for AA1XXX series) and different aluminium alloys in 
TABle 1: AA Designation of wrought aluminium and its alloys [1, 2].

\begin{tabular}{lc}
\hline Alloying elements & Series designation \\
\hline Pure aluminium & AA1XXX \\
Copper & AA2XXX \\
Manganese & AA3XXX \\
Silicon & AA4XXX \\
Magnesium & AA5XXX \\
Magnesium and silicon & AA6XXX \\
Zinc & AA7XXX \\
Lithium & AA8XXX \\
\hline
\end{tabular}

TABLE 2: AA Designation of cast aluminium and its alloys $[1,2]$.

\begin{tabular}{lc}
\hline Alloying elements & Series designation \\
\hline Pure aluminium & AA1XX.X \\
Copper & AA2XX.X \\
Silicon, with copper and/or & AA3XX.X \\
magnesium & AA4XX.X \\
Silicon & AA5XX.X \\
Magnesium & AA7XX.X \\
Zinc & AA8XX.X \\
Lithium
\end{tabular}

the group (for other series) are represented by the third and fourth digits $[1,2]$.

The castings and foundry ingots of $\mathrm{Al}$ and its alloys are designated (Table 2) by a four-digit number with the incorporation of a decimal point. Number 1 in the first digit stands for aluminium with high purity. The second and third digits are used for minimum Al percentage. The fourth digit is used after decimal point and it is 1 for cast ingot and 0 for casting.

2.1. Effect of Alloying Elements in AA6XXX Alloys. Pure aluminium is soft and formable. Aluminium is frequently alloyed in order to increase strength. The alloying also affects the weldability, corrosion resistance, stress corrosion cracking, conductivity, and density. AA6XXX aluminium alloys can be strengthened by the following major strengthening mechanisms along with the solid solution strengthening:

(i) grain-boundary strengthening [3, 4],

(ii) precipitation or age hardening $[3,4]$,

(iii) work hardening $[3,4]$.

The AA6XXX alloy design $[1,2,5]$ aims at significant enhancement of properties. The properties depend on microstructure of metals and alloys. Hence, the final goal of the alloy design is to design a perfect microstructure so that the principal goal such as strength, ductility, and toughness along with other properties like corrosion resistance, stress corrosion cracking resistance, and fatigue resistance are enhanced. The role of composition (Table 3) of metals and alloys is not insignificant because it provide the suitable structure with enhanced properties.

The major alloying elements of AA6XXX series alloys are $\mathrm{Si}$ and $\mathrm{Mg}$. The addition of these two alloying elements is done in the proper ratio to form $\mathrm{Mg}_{2} \mathrm{Si}$ valence compound. $\mathrm{Mg} / \mathrm{Si}$ ratio of 1.73 is required for the formation of magnesium silicide $\left(\mathrm{Mg}_{2} \mathrm{Si}\right)$. Generally, AA6XXX alloys, produced by DC casting techniques, contain either extra Si or extra Mg. Presence of excess Si produces higher strength and higher formability but incorporates the intergranular corrosion tendency while excess $\mathrm{Mg}$ increases the corrosion resistance but reduces formability and strength. The formation of $\mathrm{Mg}_{2} \mathrm{Si}$ precipitates give rise to the simple eutectic system with aluminium. At elevated temperature, the solute element dissolves in the solid solution but because of the decrease in solubility at lower temperature forms age-hardenable $\mathrm{Mg}_{2} \mathrm{Si}$ precipitates.

Copper has appreciable solubility and strengthening effect. The addition of $\mathrm{Cu}$, in variable concentrations, produces substantial solid solution and precipitation strengthening. In presence of magnesium and silicon, copper produces agehardening effects at room temperature. The weldability and corrosion resistance are decreased and the weight of the alloy is increased with the copper addition.

During the extraction processing of aluminium from alumina trace elements like $\mathrm{Fe}, \mathrm{Na}, \mathrm{Li}, \mathrm{Ca}, \mathrm{Ti}, \mathrm{V}, \mathrm{Cr}$, and compounds such as oxides, nitrides, borides, carbides, and $\mathrm{H}$ can go into the structure. All traces are not harmful for the properties of $\mathrm{Al}$ and its alloys. Elements like $\mathrm{Cr}, \mathrm{Ti}, \mathrm{Li}$ play crucial role in properties enhancement and sometime additions of those elements are deliberate. The deliberate additions of trace elements like $\mathrm{Cr}, \mathrm{Mn}, \mathrm{Zr}$, and Sc can restrict the softening mechanisms during elevated temperature deformation. The fine grain structure ensures strengthening by grain refinement and work hardening. The trace elements show significant role (Table 4) in altering the physical, mechanical, and corrosion behavior of $\mathrm{Al}$ and its alloys.

The presence of trace elements Fe in AA6XXX alloys, as $\mathrm{FeAl}_{3}, \mathrm{Fe}_{2} \mathrm{SiAl}_{8}, \mathrm{FeMg}_{3} \mathrm{Si}_{6} \mathrm{Al}_{8}$, and $\mathrm{FeAl}_{6}$ can be harmful for the properties of these alloys. Iron hinders ductility and toughness by the formation of coarse constituent with $\mathrm{Al}$ and other alloying elements such as $\mathrm{Cu}, \mathrm{Ni}, \mathrm{Mn}$, and Si. Iron reduces the strength and decreases the corrosion resistance and fatigue resistance. Additions of $\mathrm{Cr}$ and $\mathrm{Mn}$ alloying elements are done as the Fe corrector of AA6XXX alloys to correct the shape and size of the iron-bearing precipitates, while restricted addition of $\mathrm{Zn}$ can cause extra strengthening without much loss in corrosion resistance. The presence of Manganese not only raises the recrystallization temperature but also shows strengthening by both the dispersion hardening and the age hardening. It also enhances the corrosion resistance.

Alloying elements B, Ti in some AA6XXX alloys cause the control of grain size and produce grain boundary strengthening of those alloys. The machinability can be higher by the addition of $\mathrm{Bi}$ and $\mathrm{Pb}$ in AA6XXX alloys. The solid solution strengthening to some extent can be caused by lattice parameter control in commercial alloys due to presence of $\mathrm{Mg}$ and $\mathrm{Si}$ in solid solution. 
TABle 3: Composition of AA6XXX alloys [6-8].

\begin{tabular}{lcccccc}
\hline Designation & Si, $\%$ & $\mathrm{Mg}, \%$ & $\begin{array}{c}\mathrm{Cu}, \% \\
\text { maximum }\end{array}$ & $\begin{array}{c}\mathrm{Mn}, \% \\
\text { maximum }\end{array}$ & $\begin{array}{c}\text { Cr, \% } \\
\text { maximum }\end{array}$ & Others, \% \\
\hline AA6003 & $0.35-1.0$ & $0.8-1.5$ & 0.10 & 0.8 & 0.35 & - \\
AA6005 & $0.6-1.0$ & $0.4-0.6$ & 0.10 & 0.10 & 0.10 & - \\
AA6053 & $0.44-1$ & $1.1-1.4$ & 0.10 & - & $0.15-0.35$ & - \\
AA6061 & $0.4-0.8$ & $0.8-1.2$ & $0.15-0.40$ & 0.15 & $0.04-0.35$ & - \\
AA6063 & $0.2-0.6$ & $0.45-1.0$ & 0.10. & 0.10 & 0.10 & - \\
AA6066 & $0.9-1.8$ & $0.8-1.4$ & $0.7-1.2$ & $0.6-1.1$ & 0.40 & - \\
AA6070 & $1.0-1.7$ & $0.50-1.2$ & $0.15-0.40$ & $0.4-1.0$ & 0.10 & B 0.06\% maximum. \\
AA6101 & $0.3-0.7$ & $0.35-0.8$ & 0.10 & 0.03 & 0.03 & - \\
AA6105 & $0.6-1.0$ & $0.45-0.8$ & 0.10 & 0.10 & 0.10 & - \\
AA6151 & $0.6-1.2$ & $0.45-0.8$ & 0.35 & 0.20 & $0.15-0.35$ & - \\
AA6162 & $0.4-0.8$ & $0.7-1.1$ & 0.20 & 0.10 & 0.10 & B 0.06\% maximum. \\
AA6201 & $0.5-1.0$ & $0.6-1.0$ & 0.10 & 0.03 & 0.03 & Zn 1.6-2.4\% \\
AA6253 & $0.4-1.05$ & $1.0-1.5$ & 0.10 & - & $0.04-0.35$ & Pb and Bi 0.4-0.7\% each \\
AA6262 & $0.4-0.8$ & $0.8-1.2$ & $0.15-0.40$ & 0.15 & $0.04-0.14$ & - \\
AA6351 & $0.7-1.3$ & $0.4-0.8$ & 0.10 & $0.4-0.8$ & - & - \\
AA6463 & $0.2-0.6$ & $0.4-1.0$ & 0.20 & 0.05 & 0.10 & - \\
\hline
\end{tabular}

TABLe 4: Trace elements in $\mathrm{Al}$ and its alloys [2].

\begin{tabular}{|c|c|c|}
\hline Trace elements & Concentration (wt \%) & Properties \\
\hline $\mathrm{H}$ & 0.0001 & $\begin{array}{l}\text { Presence of } \mathrm{S}, \mathrm{Mg} \text { and } \mathrm{Li} \text { increase the absorption of } \mathrm{H} \text { while } \mathrm{Si}, \mathrm{Sn}, \mathrm{Cu} \text {, and Be reduce it. } \\
\text { Formation of gas porosity after solidification. }\end{array}$ \\
\hline Fe and $\mathrm{Si}$ & $0.1-1.0$ & $\begin{array}{l}\text { Formation of } \mathrm{Al}_{3} \mathrm{Fe} \text { and } \mathrm{AlFeSi} \text { second phase compounds, which reduce the fatigue and fracture } \\
\text { properties of } \mathrm{Al} \text { alloys. }\end{array}$ \\
\hline $\mathrm{Na}, \mathrm{Li}$ and $\mathrm{Ca}$ & $<0.01$ & $\begin{array}{l}\text { These elements enhance the Al-Si eutectic structure resulting in higher strength properties and } \\
\text { pressure tightness effect. Rolling might be difficult because of formation of edge cracking } \\
\text { tendency. Li increases the strength at elevated temperatures, maintaining low density. }\end{array}$ \\
\hline $\mathrm{Ti}, \mathrm{V}, \mathrm{Cr}, \mathrm{Mn}$ & $0.001-0.05$ & $\begin{array}{l}\text { Cause grain refinement during solidification, retard recrystallization during deformation. } \\
\text { Presence of Mn also acts as Fe-corrector correcting the shape of Fe bearing precipitates. }\end{array}$ \\
\hline $\mathrm{Ga}$ & $0.001-0.02$ & The corrosion behavior, etching, and brightening of some alloys are altered. \\
\hline
\end{tabular}

\section{Processing of AA6XXX Alloys}

Processing of $\mathrm{Al}$ and its alloys plays very crucial effect on the property determination. As earlier explained properties of $\mathrm{Al}$ alloys principally depend on their microstructure and their constituents such as average grain size, grain size distribution, precipitate volume fraction, and number fraction and the crystallographic orientation aspects like texture of $\mathrm{Al}$ and its alloys [6-10]. The composition is designed to render certain structure and texture in $\mathrm{Al}$ alloys after solidification but such structure and texture can further be developed by incorporating different processing methods like metal working fabrications such as rolling, forging, extrusion, wire drawing, forming, annealing, and age hardening. The manipulation of process parameters in metal working, subsequent annealing, and aging treatment shall be able to produce diverse structures with same composition. That manifests the significance of work hardening and microprocesses such as recovery, recrystallization, and grain growth to design the desired properties of $\mathrm{Al}$ alloys.
Hence, composition and processing both are inseparable tools for developing the desired structure with enhanced mechanical properties. The details of processing of $\mathrm{Al}$ alloys are reflected by the following temper designation (Table 5) letters, which follows the alloy designation [2, 11, 12]. This temper designation is used for all forms of wrought and cast $\mathrm{Al}$ alloys except ingot and it is based on the sequence of processing used to produce the following tempers such as fabrication, work hardening, annealing, solution, and stabilization treatment.

The temper designation $\mathrm{H}$, which is suitable for wrought products, is not only involved with the work hardening process but also involved with two other elevated temperature treatments, namely, subsequent partial recrystallization annealing and stabilization heat treatments for $\mathrm{Al}$ alloys, which are liable to soften by over ageing process. The subdivisions of work hardening $(\mathrm{H})$ are following (Table 6).

Apart from the heat-treatment process involved in $\mathrm{H}$ temper, separate heat-treatment process for cooling from elevated temperature, natural, artificial, step aging process, 
TABLe 5: Basic temper designation of $\mathrm{Al}$ alloys $[2,11,12]$.

\begin{tabular}{|c|c|c|}
\hline Temper & Treatment & Use \\
\hline $\mathrm{F}$ & Fabricated & $\begin{array}{l}\text { The products fabricated by casting, hot working, cold working processes without control over elevated } \\
\text { temperature treatment or work hardening is used. }\end{array}$ \\
\hline $\mathrm{O}$ & Annealed & $\begin{array}{l}\text { The castings which are annealed to enhance ductility and dimensional stability. The wrought semis which } \\
\text { are annealed to obtain lowest strength temper. }\end{array}$ \\
\hline $\mathrm{H}$ & Strain hardened & $\begin{array}{l}\text { The wrought products only which are work hardened with or without supplementary elevated temperature } \\
\text { treatments to get desired ductility at lower strength. The } \mathrm{H} \text { is always followed by two or greater than two } \\
\text { digits. }\end{array}$ \\
\hline W & Solution treated & $\begin{array}{l}\text { The alloys which age at room temperature after solution heat-treatment to produce unstable temper. This } \\
\text { designation is proper only when the time of the aging is indicated. }\end{array}$ \\
\hline $\mathrm{T}$ & Stable tempers & $\begin{array}{l}\text { The products which show stable tempers after heat treatment with or without supplementary } \\
\text { work-hardening. The } \mathrm{T} \text { is always followed by one or several digits. }\end{array}$ \\
\hline
\end{tabular}

Table 6: Subdivision of $\mathrm{H}$ temper $[2,11,12]$.

\begin{tabular}{lll}
\hline Subdivisions & Treatment & Use \\
H1 & Work hardened & $\begin{array}{l}\text { Only work hardened products without elevated temperature treatment. The H1 is followed by } \\
\text { digits, which show the degree of work hardening. }\end{array}$ \\
H2 & $\begin{array}{l}\text { Work hardened and } \\
\text { partially annealed } \\
\text { strength. The H2 is followed by digits, which show the residual work hardening after partial } \\
\text { annealing. }\end{array}$ \\
W3 & $\begin{array}{l}\text { The properties of work hardened products are stabilized either by low temperature treatment or } \\
\text { stabilized }\end{array}$ & $\begin{array}{l}\text { by the heat introduced by fabrication. The stabilization of properties is crucial to restrict the age } \\
\text { softening of these products. The H3 is followed by digits, which show the remaining work } \\
\text { hardening after stabilization. }\end{array}$ \\
\hline
\end{tabular}

the combination of stress relieving, and step aging is designated by $\mathrm{T}$ temper. The digit following the letter $\mathrm{T}$ indicates the type of heat treatment used in Al alloys. The description of T temper in terms of treatment and use is shown in Table 7.

3.1. Homogenization. The first processing step after melting and DC casting is known as homogenization of AA6XXX alloys. The homogenization treatment of castings and ingots is performed at elevated temperature, $\left(460^{\circ} \mathrm{C}-550^{\circ} \mathrm{C}\right)$ which reduces the micro segregation in the castings and ingots, and this can produce compositional homogeneity [13-16]. This homogenization treatment of microstructure plays significant role on the subsequent processing stages such as hot working, cold working, and annealing. The homogenization treatment produces the uniform composition and is feasible when the diffusion distances are short and dendrite cell size and arm spacing are not big. The homogenization heat treatment contains the following phenomena in $\mathrm{Al}$ alloys [13-16]:

(i) uniformity in composition,

(ii) precipitation of supersaturated elements,

(iii) reduction of microsegregation,

(iv) dissolution of unstable phases or precipitates,

(v) size enlargement of stable intermetallics,

(vi) grain growth.

The nonuniform solid solubility and diffusion rate in the $\mathrm{Al}$ matrix of the alloying and trace elements make the effect of homogenization treatment diverse [17-20]. Alloying elements $\mathrm{Cr}, \mathrm{Mn}, \mathrm{V}$, and $\mathrm{Zr}$ show very low diffusion rate, Fe shows low solubility and low diffusion while $\mathrm{Cu}, \mathrm{Mg}$, $\mathrm{Si}$, and Zn show high solubility and high diffusion rates. Alloying elements like $\mathrm{Fe}, \mathrm{Cr}, \mathrm{Mn}, \mathrm{V}$, and $\mathrm{Zr}$ if present in the $\mathrm{Al}$ alloy hinder the homogenization process and make difficult to dissolve inclusion during homogenization. In the $\mathrm{Zr}$ - and Sccontaining $\mathrm{Al}$ alloys, fine dispersion of $\mathrm{Al}_{3} \mathrm{Zr}, \mathrm{Al}-\mathrm{Sc}, \mathrm{Al}-\mathrm{Mg}-$ $\mathrm{Sc}$ is formed which has beneficial effect on the properties of $\mathrm{Al}$ alloys refining the grain size. In Fe, bearing AA6XXX alloys the transformation of metastable phase $\left(\mathrm{FeAl}_{3}\right)$ to stable phase $(\alpha-\mathrm{Al}(\mathrm{Fe}, \mathrm{Mn}) \mathrm{Si})[16,17]$ is as

$$
\mathrm{FeAl}_{3} \longrightarrow \beta-\mathrm{AlFeSi} \longrightarrow \alpha-\mathrm{Al}(\mathrm{Fe}, \mathrm{Mn}) \mathrm{Si} .
$$

The homogenization treatment can increase the size of Mncontaining dispersoids [2], which can later contribute in recrystallization by self-annealing of AA6XXX alloys just after hot rolling. The self-annealing is enhanced by the presence of large Mn-containing dispersoids, which provide the particle stimulated nucleation at elevated temperature $\left(350^{\circ} \mathrm{C}\right)$ just after hot working in AA6XXX alloys. The selfannealing of AA6XXX alloys just after the hot rolling eliminates the possibility of surface-roughening phenomenon, that is, roping during subsequent forming process. Conventionally, the chances of roping are prevented by recrystallization annealing (continuous or batch annealing) treatment before or between cold working process but that increase the cost of processing and also the ability to solution treatment of the final sheet. The two-stage homogenization treatment (first stage at $550^{\circ} \mathrm{C}$ and subsequently second stage at $460^{\circ} \mathrm{C}$ ) 
TABle 7: Designation of elevated temperature treatments $[2,11,12]$.

\begin{tabular}{|c|c|c|}
\hline Temper & Treatment & Use \\
\hline $\mathrm{T} 1$ & $\begin{array}{l}\text { The elevated temperature fabrication process followed } \\
\text { by stable temper aging. }\end{array}$ & $\begin{array}{l}\text { The products are not worked at ambient temperature } \\
\text { following elevated temperature fabrication. The product } \\
\text { properties cannot recognize the ambient temperature } \\
\text { straightening and flattening effects. }\end{array}$ \\
\hline $\mathrm{T} 2$ & $\begin{array}{l}\text { The elevated temperature fabrication process followed } \\
\text { by ambient temperature working and stable temper } \\
\text { aging. }\end{array}$ & $\begin{array}{l}\text { The strength of the products is enhanced by ambient } \\
\text { temperature working and the product properties can } \\
\text { recognize the flattening or straightening effects. }\end{array}$ \\
\hline T3 & $\begin{array}{l}\text { Solution heat treated, cold worked, and aged to a } \\
\text { substantially stable condition. }\end{array}$ & $\begin{array}{l}\text { The strength of the products is enhanced by ambient } \\
\text { temperature working after solution treatment and the } \\
\text { product properties can recognize the flattening or } \\
\text { straightening effects. }\end{array}$ \\
\hline $\mathrm{T} 4$ & $\begin{array}{l}\text { Solution heat treated and aged to a substantially stable } \\
\text { condition. }\end{array}$ & $\begin{array}{l}\text { The products are not worked at ambient temperature } \\
\text { following solution heat treatment. The product properties } \\
\text { cannot recognize the ambient temperature straightening and } \\
\text { flattening effects. }\end{array}$ \\
\hline T5 & $\begin{array}{l}\text { Cooled from an elevated temperature shaping process } \\
\text { and artificially aged. }\end{array}$ & $\begin{array}{l}\text { The products are not worked at ambient temperature } \\
\text { following elevated temperature fabrication. The product } \\
\text { properties cannot recognize the ambient temperature } \\
\text { straightening and flattening effects. }\end{array}$ \\
\hline T6 & Solution heat treated and then artificially aged. & $\begin{array}{l}\text { The products are not cold worked after solution } \\
\text { heat-treatment or in which the effect of cold work in } \\
\text { flattening or straightening may not be recognized in } \\
\text { mechanical property limit. }\end{array}$ \\
\hline $\mathrm{T} 7$ & Solution heat treated and overaged/stabilized. & $\begin{array}{l}\text { The artificial aging of the wrought product after the solution } \\
\text { heat-treatment to beyond the point of highest strength. }\end{array}$ \\
\hline $\mathrm{T} 8$ & $\begin{array}{l}\text { Solution heat treated, ambient temperature worked, } \\
\text { and then artificially aged. }\end{array}$ & $\begin{array}{l}\text { The strength of the products is enhanced by ambient } \\
\text { temperature working after solution treatment and the } \\
\text { product properties can recognize the flattening or } \\
\text { straightening effects. }\end{array}$ \\
\hline T9 & $\begin{array}{l}\text { Solution heat treated, artificially aged, and then work } \\
\text { hardened. }\end{array}$ & The work hardening to enhance strength after artificial aging. \\
\hline $\mathrm{T} 10$ & $\begin{array}{l}\text { Cooled from an elevated temperature shaping process, } \\
\text { cold worked and then artificially aged. }\end{array}$ & $\begin{array}{l}\text { The products which are cold worked to improve strength or } \\
\text { in which the effect of cold work in flattening or straightening } \\
\text { is recognized in property limits. }\end{array}$ \\
\hline Tx51 & Stress relieving before ageing. & \\
\hline Tx52 & Stress relieving by compressing. & \\
\hline Tx54 & $\begin{array}{l}\text { Stress relieving by combined stretching and } \\
\text { compressing. }\end{array}$ & \\
\hline T72 & Corrosion resistance is enhanced by overaging. & \\
\hline T73 & Corrosion resistance is enhanced by step aging. & \\
\hline T76 & $\begin{array}{l}\text { Step aging leading to enhancement of exfoliation } \\
\text { corrosion behavior }\end{array}$ & \\
\hline $\begin{array}{l}\mathrm{T} 73 \times 51 \\
\mathrm{~T} 76 \times 51\end{array}$ & Combined stress relieving/step ageing & \\
\hline
\end{tabular}

can be prescribed for AA6XXX alloys to increase the size of Mn-containing dispersoids and to bring its effect on re-crystal-li-za-tion during self-annealing of AA6XXX [2, 13-20]. The presence of Mn, Cr, Zr, and Sc can hinder the recrystallization during self-annealing by pinning grain boundary [21]. The concentration of those elements should be kept low when the self-annealing is aimed just after hot working in AA6XXX alloys.

The removal of trace element $\mathrm{H}$ from castings and ingots can be possible by proper selection of homogenization temperature and time. The slow heating to an elevated temperature and presence of fluoride in furnace atmosphere during homogenization gradually removes $\mathrm{H}$ from $\mathrm{Al}$ alloys [2]. The surface oxidation and localized melting during homogenization should be avoided by selection of proper furnace atmosphere and slow heating.

3.2. Hot Working. Hot working processes such as rolling and extrusion are the first metal working processing of the DC cast ingot of AA6XXX alloys which converts DC cast 
ingots into wrought product [3]. The plastic deformation of AA6XXX takes place during metal working process, which is classified according to the type of force associated with. Rolling and forging are direct compression type, the extrusion and deep drawing are of indirect compression category while the stretch forming is tension-type metal working. The metal working is classified depending upon the temperature of plastic deformation in two broad categories, namely, hot working and cold working.

Hot working by rolling and forging of AA6XXX alloys is done at elevated temperature ( $>0.5 T_{0}$, while $T_{0}$ if the melting point of AA6XXX alloys) with high strain rate. The hot working starting temperature is around $460^{\circ} \mathrm{C}$ while the hot working finish temperature is around $330^{\circ} \mathrm{C}[15,22-24]$. The temperature of work piece in hot working depends on [3]:

(i) initial temperature of tools and work piece,

(ii) heat generation due to plastic deformation,

(iii) heat generation by friction,

(iv) heat transfer between the deforming alloy and surroundings.

Strain during the hot working of AA6XXX alloys by rolling and forging process is large compared with creep and tension test and the strain rate is in the range of $\left(0.5 \mathrm{~s}^{-1}-500 \mathrm{~s}^{-1}\right)$ [3]. The conventional hot rolling of AA6XXX alloys is done in two stages, first by breakdown mill, which produces the transfer slab of $30-50 \mathrm{~mm}$ thick and later by tandem mill (3-5 stand), which produces around $6 \mathrm{~mm}$ thick sheet of AA6XXX alloy [15]. Deformation capability of work piece is enhanced at elevated temperature and alloy work piece shows high plasticity enabling the large deformation reductions without consumption of high energy. Salient features of hot working are the following $[3,15]$ :

(i) complete elimination of cast dendritic structure,

(ii) no existence of elongated grains produced by rolling and extrusion,

(iii) virtually no strain hardening and flow stress becomes constant,

(iv) large plastic deformation capability,

(v) Replacement of deformation structure by microprocess such as simultaneous dynamic recovery and rapid recrystallization and formation of strain free structure $[10,15]$.

The microprocess such as dynamic recovery phenomenon can be widely observed during hot working by vacancy migration induced dislocation movement by climb process and cross slip (cross slip is valid only for screw dislocations) at elevated temperature. The initial hot deformation produces dislocations, which accumulate in tangles and form subboundaries by dynamic recovery process [10]. The resulting subgrain structures are stable in size during steadystate deformation, that is, at constant stress, strain rate, and temperature of hot working process. During dynamic recovery, size of the subgrains, increases with the process temperature and decreases with strain rate [3]. Stacking fault energy plays the crucial role in controlling the dynamic recovery. Generally, alloys with high stacking fault energy are favored for dynamic recovery for both the rate controlling recovery processes cross slip or climb of dislocation. The presence of alloying elements in solid solution reduces the stacking fault energy and increases the separation of partial screw dislocation, which will be hard to recover dynamically during hot working process by cross-slip. The recovery by dislocation climb is also hindered by lowering of stacking fault energy. (In this context either the theory of constriction of the fault, which needs elastic energy, depending on the width of fault between the partial jogs, or the theory of advancement of extended jogs by absorption of multiple vacancies, which is determined by the fault width is applicable.) Recrystallization, occurring during or just after the hot deformation, produces the strain-free grains surrounded by high-angle grain boundaries. Initiation of dynamic recrystallization depends on the critical strain rate and strain which occurs during hot rolling. The critical sized subgrains surrounded by favorable misorientations (for growth) present in the deformed and recovered substructure can produce the nuclei for recrystallization, which follow the subsequent growth to replace the deformed substructure and result in formation of strain-free grains discontinuously [15, 25-30]. The addition of alloying elements such as $\mathrm{Ti}, \mathrm{B}, \mathrm{Zr}$, and $\mathrm{Sc}$ usually retard the grain-boundary migration and hinder the recrystallization during and just after hot working process. Presence of precipitates in AA6XXX alloys can also pin the dislocation, cell wall, and grain-boundary movement during the microprocesses such as deformation, recovery, and recrystallization. The contribution of precipitates on these phenomena depends on the precipitate size, interprecipitate distance, or the derived volume fraction of precipitates $[10$, 31]. The cell size and the subgrain size are reduced due to presence of precipitates by the pinning process and by the formation of deformation zone (with reduced cell size) around the precipitates. Larger precipitates or dispersoid, produced by two-stage homogenization treatment during the processing of AA6XXX alloys, generally give rise to particle, stimulated nucleation which helps in nucleation of recrystallization grains during self-annealing of AA6XXX alloys while smaller precipitates restrict the grain boundary migration during recrystallization.

(vi) The solidification texture of AA6XXX alloy is converted to hot rolling texture (Table 8), which has been well studied and contains the recrystallization texture cube orientation (intensity of cube orientation in hot-rolled AA6XXX is much lower than that of hotrolled AA1XXX alloy) and remnants of deformation texture orientation such as $\mathrm{S}$, brass, and copper in the partially recovered aluminium alloys [30]. Presence of large precipitates randomizes the hot-rolled texture and decreases the cube texture intensity. However, the formation of texture during hot rolling strongly depends on the composition of this alloy and process parameters like strain, strain rate, and hot working temperature. 
TABLE 8: Volume fraction of crystallographic textures of AA6XXX alloys [33-35].

\begin{tabular}{lccccc}
\hline Products & cube & Goss & Bs & Cu \\
\hline Reroll after self-annealing & 30.00 & 3.10 & 4.50 & 3.30 & 14.30 \\
Conventional-reroll & 36.00 & 2.40 & 2.70 & 2.30 & 14.40 \\
Batch annealed-reroll & 36.60 & 1.80 & 3.00 & 2.60 & 14.60 \\
Batch annealed-final gauge (self-annealed during HR) & 10.00 & 2.20 & 5.60 & 6.60 & 14.40 \\
T4 Conventional-final gauge & 11.40 & 3.30 & 4.00 & 1.60 \\
T4 Random & 3.50 & 3.50 & 6.60 & 6.60 & 14.00 \\
\hline
\end{tabular}

During hot working, large strain is involved. Hence, the strain hardening is not desirable. Lower limit of hot working temperature for AA6XXX alloys can be based on the lowest temperature at which rapid recrystallization occurs to avoid strain hardening [3]. Recrystallization temperature depends on the degree of deformation, and for large degree of deformation, the hot working temperature reduces. Upper limit of hot working temperature is determined by either heavy oxidation or localized melting due to grain-boundary segregation of solute elements. The multiple pass hot working is widely used process for AA6XXX Al alloys. In multiple pass processing, the temperature in all passes is kept above minimum temperature for recrystallization. And the temperature of last pass is kept low to enhance the formation of fine grains, which can also be ensured by providing slightly larger deformation ( $45 \%$ thickness reduction) at the last pass. The hot working of AA6XXX alloys has the following advantages [3]:

(i) the higher plastic flow at elevated temperature makes plastic deformation easier,

(ii) accelerated diffusion during hot working reduces the cast inhomogeneities in composition,

(iii) blow holes and pin holes of cast ingot eliminated by welding of cavities,

(iv) cast dendritic inhomogeneous structure is replaced by equiaxed strain-free grains, which provide higher ductility and toughness.

Magnesium, as the alloying element, has significant effect on the hot workability of AA6XXX alloys, however, $\mathrm{Si}, \mathrm{Cu}$, and $\mathrm{Fe}$ in this regard are not very effective. Alloying elements, namely $\mathrm{Cr}, \mathrm{Mn}$, and specially $\mathrm{Zr}$ tend to enhance the press effect and provide higher strength [2]. The hot working of $\mathrm{Mg}_{2} \mathrm{Si}$ containing slab spheroidizes the $\mathrm{Mg}_{2} \mathrm{Si}$ and induces coagulation, which reduces the number of $\mathrm{Mg}_{2} \mathrm{Si}$ precipitates $[2]$.

3.3. Cold Working. During hot working at elevated temperature, oxidation takes place, also the expansion and contraction during elevated temperature treatment result in poor surface finish. In order to enhance the surface condition and strength, wrought AA6XXX alloys are cold worked after hot working [3]. Aiming at the multiplication of dislocation density the cold working renders work hardening. The strength exhibited AA6XXX Al alloy after cold working is much higher than shown after hot working, which is very much desired for structural applications in automobile, aerospace, and marine sector. Plastic deformation of AA6XXX alloy is performed at room temperature during cold working, where these alloys show less plasticity thereby restricting large reductions during cold working in a single pass. In multipass cold rolling mill, used for cold rolling of AA6XXX $\mathrm{Al}$ alloy, total cold deformation is done by several rolling stands. The hardness and strength of the rerolled (cold rolled) sheet gradually increase from the entry stand to exit rolling stand. The optical microstructure study (up to 2000X) after cold rolling reveals the elongated grains with high aspect ratio. Grains elongate along the cold working direction, whereas along normal direction the grains squeeze. With the higher percentage of cold deformation, the grains appear as long bands parallel to the working direction. At higher magnification, many other features of the deformed substructure such as the grain subdivision, cell structure, and dislocation can be revealed by electron microscope (TEM) [32]. The cell structure study of cold worked Al alloys has already been well studied. Cell structure is composed of cell wall and cell interior. The tight-packed dislocations generally form the cell wall. Dislocation density of cell interior is less than that at the cell wall. Work hardening during cold working depends on the cell size, the fraction of cell wall, and the fraction of cell interior. Recent research shows that (Figure 1) deformation-induced cell size in AA6XXX alloys varies with strain rate during dynamic loading conditions [32]. The subdivision of grain and grain rotation during the cold deformation produce deformation texture. The hotrolled texture is usually replaced by deformation texture, which comprises with the S, copper, and brass texture orientations. Cold deformation gradually reduces the cube texture intensity of hot deformed $\mathrm{Al}$ alloy. The cube-oriented grains rotate causing change in orientation. Copper and brass type of shear of grains produce the deformation texture. The deformed substructure, which can be observed under high magnification, would be heterogeneous $[10,25]$. The presence of transition and shear band in the deformed structure produces the deformation inhomogeneity.

3.4. Annealing. Annealing process is conventionally performed before cold working or between cold working (intermediate/process annealing). Annealing is of two types batch and continuous annealing. AA6XXX alloy hot-rolled sheets are reheated in furnace during batch annealing process in the temperature regime $380^{\circ} \mathrm{C}-460^{\circ} \mathrm{C}$ (Table 9), while in continuous annealing, slightly elevated temperature around 

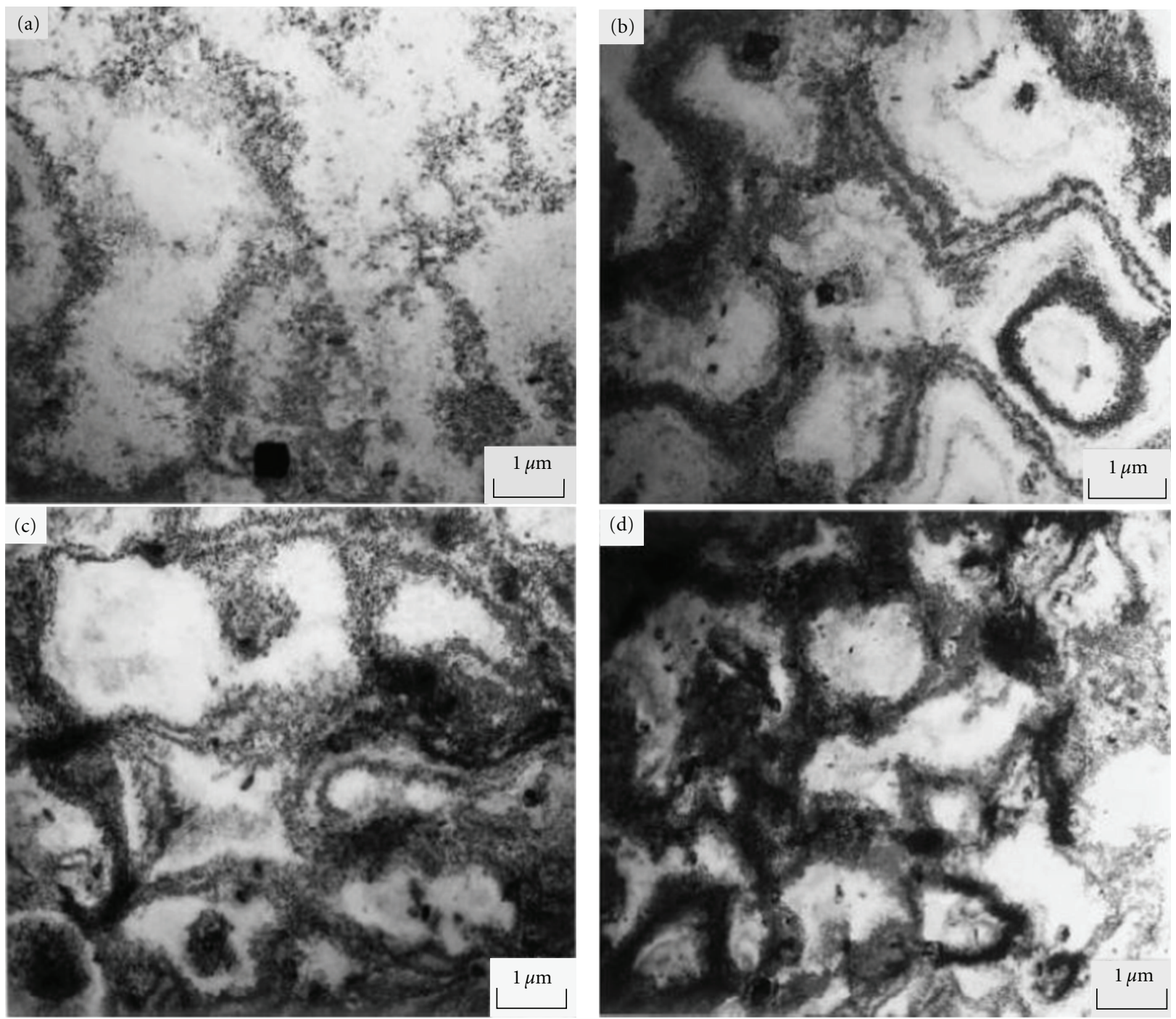

Figure 1: Dislocation substructure [32] of AA6061-T6 aluminium alloy at strain rates (a) $10^{-3} \mathrm{~s}^{-1}$, (b) $2 \times 10^{-3} \mathrm{~s}^{-1}$, (c) $3 \times 10^{-3} \mathrm{~s}^{-1}$, and (d) $4 \times 10^{-3} \mathrm{~s}^{-1}$ at true strain 0.25 . The cell structure refined with strain rate.

$510^{\circ} \mathrm{C}$ is used for aluminium alloy sheets [26]. In AA6XXX, softening of the sheet occurs during annealing which is intentionally designed to induce plastic deformation capability during cold rolling. Subsequent formation of strain-free equiaxed grains induces softness due to absence of dislocations. The last step for cold rolling-intermediate annealing process can be annealing when soft final gauge is required while last step can be cold rolling when high strength of final gauge is required. Strength and hardness of the final gauge produced can be varied by manipulating the combined process cold rolling and intermediate annealing.

The strain-free grains and the crystallographic texture, which are formed during annealing, determine the subsequent final forming character of AA6XXX alloy sheets. cube texture orientation, after annealing, is the characteristic of aluminium [27]. Presence of large precipitates randomizes the cube texture in aluminium alloys $[25,30]$. The large precipitates form the deformation zone during cold working in the surrounding matrix and fine subgrain structure can be formed in the deformation zone by static recovery process. The presence of solutes in the solid solution and fine precipitates (of $\mathrm{Zr}, \mathrm{B}, \mathrm{Sc}, \mathrm{Ti}$ ) can hinder subgrain formation by pinning of dislocation during static recovery, which can result in no or delayed subgrain structure formation during annealing [2]. Recrystallization can occur by nucleation and growth (discontinuous recrystallization) with the driving force of very high dislocation density, or it can occur continuously without any high-angle grain-boundary migration by extended recovery of dislocation at the low-angle grain boundary which transform the low-angle grain boundary to high angle grain boundary (recrystallization in situ). The cube oriented grains generally determine the recrystallization texture in discontinuous recrystallization with the suppression of rolling texture orientations while rolling texture orientations become prominent after recrystallization in situ. Both discontinuous and continuous recrystallizations can contribute to the formation of strain-free grain after annealing in the commercial AA6XXX alloys, which have 
TABLE 9: Annealing, solutionizing, and aging: processing data [7].

\begin{tabular}{lccc}
\hline Designation & A. $T\left({ }^{\circ} \mathrm{C}\right)$ & $\mathrm{S} . T\left({ }^{\circ} \mathrm{C}\right)$ & $\mathrm{Ag} . T\left({ }^{\circ} \mathrm{C}\right)$ \\
\hline AA6053 & 413 & 520 & $171-178$ \\
AA6061 & 413 & 528 & $160-177$ \\
AA6063 & 413 & 521 & $176-183$ \\
AA6066 & 413 & 532 & $176-180$ \\
AA6070 & 413 & 546 & 160 \\
AA6463 & 413 & 521 & 177 \\
\hline
\end{tabular}

heterogeneity in solute level and precipitate distribution. The sources of nucleation of strain-free recrystallized grains $\left(N_{R}\right)$ in aluminium alloys are stable cube grains $\left(N_{C}\right)$ after deformation, deformation zones around the precipitate $\left(N_{Z}\right)$, deformation heterogeneities $\left(N_{\mathrm{HD}}\right)$ such as transition and shear bands, and also the deformed grain boundary $\left(N_{\mathrm{G}}\right)$ [25-30]. The $N$ represents the number of nuclei per unit volume:

$$
N_{\mathrm{R}}=N_{\mathrm{G}}+N_{\mathrm{C}}+N_{\mathrm{HD}}+N_{\mathrm{Z}}
$$

Whatever be the mechanism, the presence of large precipitate in AA6XXX alloy induces the particle-stimulated nucleation and randomize the cube texture after annealing recrystallization [25-30]. Extended recovery can result in the elongated band-shaped grains after recrystallization and stabilize the deformation texture orientation like $\mathrm{S}$, brass, and copper [28-30]. The conventional annealing is not only done to facilitate the cold rolling, but also to eliminate the roping defect after forming of final gauge. Self-annealing just after hot rolling of AA6XXX alloys in the temperature regime $270-300^{\circ} \mathrm{C}$ can eliminate the surface roughening by roping of AA6XXX alloy, without extra processing such as conventional annealing.

3.5. Aging Treatment. The elevated temperature treatments of AA6XXX alloys are done to regulate the properties by the formation of age-hardenable precipitates. This treatment involves solutionizing at elevated temperature around 520$550^{\circ} \mathrm{C}$ and then quenching to room temperature followed by room temperature aging or elevated temperature aging (artificial aging) in the temperature range $160-180^{\circ} \mathrm{C}[2,7$, 36-39] (Table 9). Quenching to room temperature from the solutionizing temperature produces the supersaturated solid solution (SSS). Slow cooling is avoided after SSS to prevent the separation of equilibrium precipitate from solid solution. The aging at room temperature or at elevated temperature (below the GP zone solvous) produces the nonequilibrium metastable or transition phases such as Guinier-Preston (GP) zones and hexagonal $\beta^{\prime \prime}$ and $\beta^{\prime}\left(\mathrm{Mg}_{2} \mathrm{Si}\right)$, which are coherent to the matrix and strengthening occurs. These $\beta^{\prime \prime}$ and $\beta^{\prime}\left(\mathrm{Mg}_{2} \mathrm{Si}\right)$ are coherent unlike incoherent equilibrium fcc $\mathrm{Mg}_{2} \mathrm{Si}$ and they are the source of precipitation hardening or age hardening of AA6XXX alloys. The age hardenable precipitation formation sequence in AA6XXX alloys is the following $[2,7,36-38]$ :

$$
\begin{aligned}
\text { SSS } & \longrightarrow \text { GP zones } \longrightarrow \beta^{\prime \prime} \longrightarrow \text { hexagonal } \beta^{\prime}\left(\mathrm{Mg}_{2} \mathrm{Si}\right) \\
& \longrightarrow \mathrm{fcc} \beta\left(\mathrm{Mg}_{2} \mathrm{Si}\right) .
\end{aligned}
$$

Recent observation reveals the existence of other precipitate phase like hexagonal $Q^{\prime}$ and $Q$ phases in $\mathrm{Al}-\mathrm{Mg}$-Si-Cu alloys [38]. The lath features of these two phases distinguish $Q^{\prime}$ and $Q$ phases from needle-shaped $\beta^{\prime}$ precipitate [38].

The AA6XXX alloys used in automobile industries are subjected to another elevated temperature aging treatment known as reversion and reaging (RRA) where the artificially aged AA6XXX alloys are heated to above GP solvus and then quickly aged to temperature below GP solvus. This RRA technology offers fine grain structures at the surface which are wanted for forming processes used in automobile industries.

In many AA6XXX alloys, the following sequence of processing is performed: solution treatment, preaging, deformation and final aging. The pre-aging can play crucial role to determine final properties of many AA6XXX alloys. In this process, the aging of AA6XXX alloy containing less dislocations (which is not in deformed state) can be performed at slightly lower temperature and shorter time than the normal aging. The presence of less dislocations hinders the heterogeneous nucleation of precipitates at the dislocations in the AA6XXX alloy matrix and that can lower the chance heterogeneous nucleation after deformation during final aging. The uniform distribution of precipitates, after preaging, gives rise to uniform substructure after deformation replacing the occurrence of deformation heterogeneity.

The resistance to stress corrosion cracking is enhanced by second aging treatment but the strength is slightly decreased because of overaging during second aging treatment. Repeated treatment at elevated temperatures might contribute in the loss of magnesium but the effect is not very significant. The quenching rate plays significant role for those AA6XXX alloys which contain high solute concentration of magnesium, silicon, copper, manganese, and chromium. Roomtemperature aging contributes to only limited hardening in AA6XXX alloys [2]. Cold working is sometimes performed after artificial aging to increase strength (35\% in ultimate tensile strength and $55 \%$ yield strength). The ductility (elongation up to $60-80 \%$ ) is reduced by cold working after aging. The alloying elements such as $\mathrm{Zn}$ and $\mathrm{Fe}$ do not contribute much in the aging process but $\mathrm{Cu}$ accelerates the aging while $\mathrm{Mn}$ and $\mathrm{Cr}$ can reduce the grain-boundary precipitations preventing embrittlement and intergranular corrosion.

\section{Strengthening Methods of AA6XXX Alloys}

4.1. Grain-Boundary Strengthening. The grain boundaries represent the misorientation surfaces between adjacent grains in polycrystalline AA6XXX and they are associated with high energy [3]. Fine-grain structures of AA6XXX alloys are wanted to exhibit high strength at the same time higher toughness. The increase in the fraction of grain-boundary surfaces, associated with fine grain structure, can be the source of strengthening. There are several mechanisms of strengthening in fine grain polycrystalline AA6XXX alloys [40-49].

(i) Activation of higher number of slip systems and mutual interference of slip systems near grain-boundary region than in the grain center, which makes effect of 
grain boundary felt in the grain center in fine grain structure.

(ii) Contribution of texture orientation dependent factor, that is, Taylor factor in the texture strengthening. Individual grains in the polycrystalline AA6XXX alloy will have different work hardening rate because of its own texture oriented deformation capability, which is reflected by the Taylor factor. In fcc AA6XXX alloys the average value of that factor is of the order of 3.10 and that textural work hardening (equivalent to $T^{2}$, where $T$ is the Taylor factor) can be 10 times higher than for AA6XXX single crystals [3].

(iii) Misoriented regions between grains or the grainsboundaries can also act as the barrier against the dislocation movement during deformation, which creates the large ( $>50$ dislocations) dislocation pile-up and cause strengthening. The dependence of yield strength on grain size of AA6XXX alloys can be represented by well-known Hall-Petch Equation, which is generally explained by the dislocation pile-up theory.

Hence, the fine grain structure of AA6XXX alloys has certain advantages in strengthening. That fine grain structure of AA6XXX alloys can be ensured during processing starting from solidification of casting to elevated temperature processing such as annealing. Grain refinement of AA6XXX alloy microstructure involves the preferential nucleation of fineequiaxed grains at the place of solidification dendrites [5055]. Higher solidification rates in DC casting than conventional sand casting can reduce the dendritic cell size or arm spacing but best grain refinement occurs because of addition of insignificant amount of master alloys (Al-5\%Ti-1\%B) in the melt before DC casting. The underlying mechanisms of grain refinement are (i) controlled heterogeneous nucleation on the $\mathrm{TiB}_{2}$, (TiAl) $\mathrm{B}_{2}$, and $\mathrm{TiC}$ particles and (ii) retardation of dendrite growth by solute elements and creation of the constitutionally supercooled zone, near the solidifying zone during solidification. In order to ensure the fine grain structure of AA6XXX alloys during elevated temperature processing from hot working to annealing, the abnormal growth of grains should be prevented. (0.1-0.5)\% addition of alloying elements such as $\mathrm{Mn}, \mathrm{Cr}, \mathrm{Zr}$, and $\mathrm{Sc}$ are very useful to ensure fine grain structure of AA6XXX alloys. The abnormal grain growth is prevented by the presence of $\mathrm{Al}_{3} \mathrm{Zr}, \mathrm{Al}_{3} \mathrm{Sc}$, and $\mathrm{Al}_{6} \mathrm{Mn}$ dispersoids of size range $(5-50 \mathrm{~nm})$. These trace elements, when added, retard recrystallization and abnormal grain growth by raising the recrystallization temperature (TR):

$$
\begin{aligned}
\operatorname{Mn} \& \operatorname{Cr}\left(\mathrm{TR} \sim 330^{\circ} \mathrm{C}\right) & <\operatorname{Zr}\left(\mathrm{TR} \sim 410^{\circ} \mathrm{C}\right) \\
& <\mathrm{Sc}\left(\mathrm{TR} \sim 605^{\circ} \mathrm{C}\right) .
\end{aligned}
$$

4.2. Precipitation Strengthening. The AA6XXX alloys are heat-treatable alloys. Precipitation of the alloying elements as coherent GP zones and coherent $\beta^{\prime \prime}$ and hexagonal coherent $\beta^{\prime}\left(\mathrm{Mg}_{2} \mathrm{Si}\right)$, during aging treatment, provides strengthening due to the presence of coherency strain field around the precipitates, which interacts with the moving dislocations
$[3,4,38]$. The presence of coherent lath-type hexagonal nonequilibrium $Q^{\prime}$ precipitates in quaternary alloys which contain $\mathrm{Cu}$ can also give rise to coherent strain field. Formation of nonequilibrium coherent hexagonal precipitation gives the highest precipitation strengthening in AA6XXX alloys $[3,38]$. The equilibrium fcc $\beta\left(\mathrm{Mg}_{2} \mathrm{Si}\right)$ or the quaternary $Q$ phases are incoherent and formation of incoherent equilibrium precipitates culminates in slight loss in hardness and yield strength due to the absence of lattice mismatch strain, that is, coherency strain around the equilibrium precipitates in AA6XXX alloys. Overaging of the fcc $\beta\left(\mathrm{Mg}_{2} \mathrm{Si}\right)$ or hexagonal $Q$ precipitates leads to coarsening of precipitates and results in further loss in yield strength, which should be prevented. Deformation-induced moving dislocation can interact with precipitates in two ways in AA6XXX alloys. Dislocation can either cut the soft coherent precipitates or bypass the hard incoherent dispersoids (the hard equilibrium or over-aged precipitates; this nomenclature is not similar to dispersion hardening phases which are fabricated by powder metallurgy route). The strengthening occurs because of these dislocation and particle interactions. The lattice mismatch strain field or coherency strain field around the dispersoid does not exist which lowers the hardness and yield strength but dispersoids in AA6XXX play the significant role in work hardening restricting the moving dislocations, which finally free from dispersoids leaving one dislocation loop around the dispersoids at higher stress. Precipitation strengthening, caused by soft coherent precipitates in AA6XXX alloys, is due to coherency strain, stacking fault energy interaction, modulus interaction, interfacial energy, and lattice friction stress [56-62]. The coherency strain field resulting from the mismatch between the precipitate and matrix can be the source of high local strength. An increase in local strength due to coherency increases with the volume fraction of coherent precipitate, radius of the precipitate, the mismatch strain field and reduces with the displacement vector of dislocation. The precipitates can have dissimilar stacking fault energy than matrix. Local variation of stacking fault width, in the precipitate and matrix, which the glide dislocation faces when it enters the precipitate from matrix, can be the source of strengthening in AA6XXX alloys, where the increase in the yield strength increases with the local variation in stacking fault, partial dislocation separation force, stacking fault width and precipitate volume fraction. The degree of strengthening due to variation in modulus of rigidity between precipitate and matrix might not be high but that increases with the size and volume fraction of precipitate, local variation in rigidity and decreases with displacement vector of dislocation. Any increment in the precipitate-matrix interface due to cutting of precipitates preferentially for the GP zones, which offer high surface-to-volume ratio, can act as source of high yield strength which increases with the volume fraction and precipitate-matrix surface energy and decreases with the size of precipitates in AA6XXX alloys. The localized increase in the yield strength due to presence of precipitate with higher yield strength than the matrix can also cause the increase in the lattice friction stress, that is, Peierls stress for the movement of dislocation. This strengthening effect increases with the increase in the volume fraction 
and size of precipitates and reduces with the displacement vector of dislocation. For incoherent [16] dispersoids, the yield stress is determined by the shear stress needed for bowing out dislocation line between two precipitates with certain interparticle distance. The interparticle distance plays prominent role in strengthening of incoherent precipitates in AA6XXX alloys.

4.3. Work Hardening. The shear strength exhibited by AA6XXX alloys continuously increase with shear strain. This phenomenon of increase in the shear strength due to previous plastic deformation is known as work hardening [3, 4]. The multiplication of dislocations raises the dislocation density during plastic deformation because of dislocation emission from steps and ledges of grain boundary, dislocation regeneration by Frank-Read mechanism when the moving dislocation is pinned between the precipitates or dispersoid or solutes, condensation of vacancies and by multiple cross slip mechanisms in AA6XXX alloys. The plastic deformation induces the movement of dislocations. During the plastic-deformation-induced movement of high population of dislocations, dislocations interact with jogs and sessile dislocations and with the other barriers present in alloys such as substructure cell wall, grain boundary, precipitate, dispersoid, and solute atmosphere [63-68]. The restriction in dislocations movement at the barriers produces the dislocation pile-up on the slip plane which generates high back stress against the applied stress. Work hardening arising from the dislocation pile-up is appreciable over larger distance and known as long-range strength, which is insensitive to temperature [3]. Hence, AA6XXX alloys can show considerable strengthening even at elevated temperature. In fcc AA6XXX alloys, two types of sessile dislocations are produced, namely, Frank partial dislocation and sessile dislocations which produce the Lomer-Cottrell barrier. The edge dislocations can be produced due to condensation of vacancies in AA6XXX alloys with the displacement vector $\left(a_{0} / 3\right)[111]$, which is normal to central stacking fault plane, where the glide of that (Frank Partial) dislocation is restricted. Frank partial dislocation cannot move or glide due to the application stress and acts as sessile barrier at ordinary temperature unless elevated temperature driven diffusion controlled climb of that dislocation occurs. At ambient temperature, the sessile barrier produced by Frank partial dislocations can provide barrier against the movement of other dislocations. Another crucial dislocation reaction which can give rise to formation of the sessile barrier is known as Lomer-Cottrel reaction in AA6XXX alloys, where the leading partials on intersecting $\{111\}$ slip planes react with each other and produce $\left(a_{0} / 6\right)[011]$ pure edge dislocation in the (100) plane and the displacement vector of the resulting dislocation does not fall in either of its planes of its stacking fault. This barrier can be through either at elevated temperature and/or at high stress. Formation of jogs in edge dislocation can also contribute to work hardening restricting the movement of edge dislocations. The dislocation-dislocation cutting process on the slip plane ranges only (6-11) interatomic spacing, raising the stress field locally which is not extended over wide range in AA6XXX alloys, hence known as short-range strength, which can be sensitive to temperature and does not prevail at elevated temperature. The metal working process produces the cellular substructure composed of cell wall and cell interior as a function of strain, strain rate, and temperature in many alloys. The shape and size of the cell structure depend also on the composition of the alloys. In aluminium, the cellular substructure, which is produced by metal working is quite stable and does not vary in size to a large extent with stain, strain rate [3]. However, possibility of cell refinement with variable strain rate is not invalid in AA6XXX alloys [32]. Cell walls act as the barrier against the mobile dislocations. The mutual interaction of immobile cell wall and cell interior dislocations with the mobile dislocation is the source of significant work hardening [66], which depends on the volume fraction of cell wall, composed of tight-packed dislocations, and cell interior which contains comparatively less dislocations than the cell wall. Cellular substructure formation during metalworking in AA6XXX alloys might successfully musk the effect the grainboundary on work hardening [66] due the fact that the majority of mobile dislocations meet the cell wall barrier first prior to meeting the grain boundary.

\section{Properties of AA6XXX Alloys}

The properties of AA6XXX alloys vary with composition and processing such as hot working, cold working, annealing, and aging processes $[2,5,7,69,70]$. Yield strength, ultimate tensile strength, elongation, shear strength, fracture strength, and hardness values for the annealed state and T6 state of some widely used AA6XXX alloys are tabulated in Table 10 and Table 11 [7]. The annealed alloys offer yield strength $(40-80 \mathrm{MPa})$ which is about half of the Ultimate Tensile Strength (85-150 MPa), while significant increase in Yield Strength and ultimate tensile strength can be observed after T6 treatment of the same alloys. T6-conditioned alloys exhibit Yield strength ranging from (210-360) MPa and ultimate tensile strength (240-385) MPa. The margin between Yield Strength and Ultimate Tensile Strength is also reduced after T6 conditioning of these alloys. A significant increase in the shear strength and fracture strength after T6 condition is observed for these alloys. However the ductility denoted by $\%$ elongation is reduced after T6 conditioning (10-15\%) compared to the \% elongation of annealed state (18-35\%). The T6 conditioning of these alloys is associated with about 3 times increase in the Brinell hardness value $(25-43 \mathrm{HB})$ compared to hardness of annealed state (73-120 HB). Mg, Si, and $\mathrm{Cu}$, alloying additions, play important role in defining the mechanical properties of AA6XXX alloys. Alloying elements such as $\mathrm{Mn}$ and $\mathrm{Cr}$ increase the strength (10-15)\%. Segregation of excess $\mathrm{Si}$ as platelets along the grain boundary raises the intergranular brittleness in fully hardened alloys. Addition of Mn counteracts this brittleness. Iron correction by $\mathrm{Mn}$ can increase toughness. Alloying elements like B, Ti, and $\mathrm{Zr}$ interact with the structure during processing and also contribute to hardening of these alloys. Young's Modulus of these alloys is about $65-70 \mathrm{GPa}$ and shear strength can be $65-70 \%$ of that of ultimate tensile strength. The ordinary and elevated temperature compressive strengths are similar 
TABLE 10: Properties of AA6XXX alloys in annealed condition [7]. Y.S: yield strength, UTS: ultimate tensile strength, El: elongation, SS: shear strength, FS: fracture strength, hardness.

\begin{tabular}{|c|c|c|c|c|c|c|}
\hline Designation & $\begin{array}{c}\text { Y.S } \\
(\mathrm{MPa})\end{array}$ & $\begin{array}{c}\text { U.T.S } \\
(\mathrm{MPa})\end{array}$ & $\begin{array}{c}\text { El. } \\
(\%)\end{array}$ & $\begin{array}{c}\text { S.S } \\
(\mathrm{MPa})\end{array}$ & $\begin{array}{c}\text { F.S } \\
(\mathrm{MPa})\end{array}$ & $\begin{array}{l}\text { H.V } \\
\text { (HB) }\end{array}$ \\
\hline AA6053 & 55 & 110 & $35 \%$ & 75 & 55 & 26 \\
\hline AA6061 & 55 & 124 & $25 \%$ & 83 & 62 & 30 \\
\hline AA6063 & 48 & 88 & $25 \%$ & 68 & 55 & 25 \\
\hline AA6066 & 83 & 152 & $18 \%$ & 96 & 68 & 43 \\
\hline AA6070 & 70 & 145 & $20 \%$ & 94 & 60 & 35 \\
\hline AA6463 & 50 & 88 & $23 \%$ & 70 & 55 & 25 \\
\hline
\end{tabular}

TABLE 11: Properties of AA6XXX alloys in T6 condition [7]. Y.S: yield strength, UTS: ultimate tensile strength, El: elongation, SS: shear strength, FS: fracture strength, hardness.

\begin{tabular}{|c|c|c|c|c|c|c|}
\hline Designation & $\begin{array}{c}\text { Y.S } \\
(\mathrm{MPa})\end{array}$ & $\begin{array}{c}\text { U.T.S } \\
(\mathrm{MPa})\end{array}$ & $\begin{array}{c}\text { El. } \\
(\%)\end{array}$ & $\begin{array}{c}\text { S.S } \\
(\mathrm{MPa})\end{array}$ & $\begin{array}{c}\text { F.S } \\
(\mathrm{MPa})\end{array}$ & $\begin{array}{l}\text { H.V } \\
\text { (HB) }\end{array}$ \\
\hline AA6053 & 220 & 255 & 13 & 160 & 88 & 80 \\
\hline AA6061 & 276 & 310 & 12 & 207 & 94 & 94 \\
\hline AA6063 & 214 & 235 & 11 & 148 & 65 & 73 \\
\hline AA6066 & 360 & 388 & 12 & 234 & 110 & 120 \\
\hline AA6070 & 352 & 378 & 10 & 234 & 94 & 120 \\
\hline AA6463 & 214 & 241 & 12 & 152 & 68 & 74 \\
\hline
\end{tabular}

as tensile strengths. Notch sensitivity of these alloys is not high. The low-temperature strength exhibited by these at the temperature $-200^{\circ} \mathrm{C}$ can be about $75 \%$ higher than room temperature strength. The fracture toughness and ductility are not altered much at low temperature. Deformation at elevated temperature shows low strength but enhanced ductility. Creep resistance is quite good at room temperature and strength is just comparable with yield strength, but with the increasing temperature, the creep resistance decreases proportionally. The corrosion resistance of these alloys is fairly good but alloys become susceptible to intergranular corrosion and stress corrosion when Cu content $(>0.4 \%)$ and $\mathrm{Si}$ content are increased. Addition of Fe without Fe corrector increases the tendency of pitting corrosion. The hot shortness problem is severe in AA6XXX alloys along Al$\mathrm{Mg}_{2} \mathrm{Si}$ line but decreases with excess either $\mathrm{Mg}$ or Si content. Hot workability of AA6XXX alloys depends on the earlier homogenization process. The two-step homogenization with second step temperature as high as $580^{\circ} \mathrm{C}$ can provide large $\mathrm{Mg}_{2} \mathrm{Si}$ dispersoids, which offer enhanced hot workability than the single-step homogeneization. The later produces fine dispersoids, which interact with the moving dislocation and cause hot working difficult [2].

\section{Use of AA6XXX Alloys}

In the last decades, great efforts have been made by the automotive giants of the world to become highly advanced and innovative to increase the fuel efficiency, reduce green house gas emissions by proper designing light weight cars and vehicles based on the intensive use of the latest developed AA6XXX aluminium alloys. In recent years, the growing attention on fuel economy and environmental factors has significantly increased the use of aluminium alloys for automotive purposes. According to the Government regulations in many countries (like USA, JAPAN and EUROPE), the cars and the vehicles have to be $15-20 \%$ more fuel efficient by 2000-2012 [71].

In view of this, the endeavor was to replace the heavier materials by lighter aluminium alloys which can reduce the weight of the vehicles and can make them fuel efficient. The data shows about $7 \%$ savings in fuel economy can be possible by reduction of weight of the car by $10 \%$ and that is also associated with significant reduction in the green house gases [72]. The average use of the aluminium per car in Western Europe lies between 100 and $400 \mathrm{~kg}$ [72]. Recently developed steels, magnesium and fiber-reinforced plastics are the competent candidate materials for this purpose; however, aluminium alloys are still standing tall among the competitors due to the associated advantages like mass production capability, good availability at a reasonable price, and good recyclability [73]. The data analysis from USA shows that $32 \%$ of the total aluminium used was in the transportation sectors [71].

The position of aluminium alloys for the transportation sectors all over the world was strengthened due to several novel concepts in light-weight solutions and applications which might need further developments in the key technology areas like flexible space frames, chassis components like axles, wheels, and body in white applications. The advancement in AA6XXX aluminium alloy use was due to its easy functional integration, tailor-made properties, and reliability which its competitors are unable to render. The availability of diversified semis such as castings, sheets, and extrusions 
TABLE 12: Use of AA6XXX alloy Rolled (R) and Extruded (F).

\begin{tabular}{lccc}
\hline Designation & $\begin{array}{c}\text { Car and light } \\
\text { weight vehicle }\end{array}$ & $\begin{array}{c}\text { Aircraft, } \\
\text { aerospace }\end{array}$ & $\begin{array}{c}\text { Marine } \\
\text { structure }\end{array}$ \\
\hline AA6061 & F & F & F \\
AA6063 & F & F & F \\
AA6013 & - & R & - \\
AA6010 & R & - & - \\
AA6016 & R & - & \\
AA6013 & - & R & - \\
AA6065 & F & - & - \\
AA6111 & R & - & - \\
AA6005 & F & - & - \\
\hline
\end{tabular}

which can be produced in mass production and can be integrated easily with their tailor-made properties has put the AA6XXX aluminium alloy development and use as strategic part of evolution of transportation industry. Extrusions of AA6XXX alloys are widely used (Table 12) in transportation sectors for aircraft, automobile, and marine structures. Underlying innovative technology and proper light-weight design with integrated functions allow these alloys to be used in flexible car concepts for the parts which required complicated shape forming such as space frames, chassis parts, bumper, crash elements, and air bags. AA6XXX alloys are generally used where quenching occurs during processing. The final strength and formability are determined by subsequent age-hardening techniques. Particularly for space frames, the properties required, such as good extrudability, excellent corrosion resistance, and weldability, are satisfied by AA6XXX alloys which can be formed at T4 condition while strength can be increased by subsequent T5 or T6 conditioning $[74,75]$.

Since the inception of car and light-weight vehicle manufacturing and aluminium alloy fabrication, the rolled aluminium alloys sheets are used for the body in white application. The potential alloys for sheet application are non-heat-treatable AA5XXX and heat-treatable AA6XXX alloys (Table 12) due to possibility of mass production, availability at reasonable price, excellent formability which can be tailored by proper alloy design and controlling the processing. The surface appearance and age-hardening response are also crucial criteria which enhance the use of AA6XXX alloys than the non-heat-treatable AA5XXX alloys. In the class of AA6XXX alloys, the sheet of AA6010, AA6016, and AA6111 alloys are generally used for sheet body of cars while recently the AA6181A alloy has been enlisted due its recycling aspects. These alloys show very high ductility in T4 condition and high strength after age hardening during paint bake cycle. The high strength and good formability of AA6111 alloys for up to $1.0 \mathrm{~mm}$ thick outer panel gauge is used in USA while in Europe the 6016 alloy is preferred for up to $1.2 \mathrm{~mm}$ thick panel gauge, which shows superior formability and higher corrosion resistance but less bake-hardened strength than AA6111 alloy.

\section{References}

[1] W. Hufnagel, Key to Aluminium Alloys, Aluminium Publication, Dusseldorf, Germany, 1999.

[2] T. R. Ramachandran, "Advances in Aluminium Processing and Its Automotive Application," Workshop Lecture Notes, pp. 2832, Indian Institute of Metals, Pune Chapter, 2006.

[3] G. Dieter, Mechanical Metallurgy, SI Metric Edition, McGrawHill, London, UK, 1988.

[4] W. D. Callister, Fundamentals of Materials Science and Engineering, John Wiley \& Sons, Hoboken, NJ, USA, 2001.

[5] J. Hirsch, B. Skrotzki, and G. Gottstein, Aluminium Alloys, Their Physical and Mechanical Properties, Wiley-VCH, Weinheim, Germany, 2008.

[6] 2010, http://aluminium.matter.org.uk/aluselect/06_composition_browse.asp.

[7] D. Kopeliovich, Wrought aluminum-magnesium-silicon alloys (6xxx), 2010, http://www.substech.com/dokuwiki/doku .php?id=wrought_aluminum-magnesium-silicon_alloys_6xxx.

[8] 2010, http://www.aluminum.org.

[9] G. Gottstein, Physical Foundations of Materials Science, Springer, Berlin, Germany, 2004.

[10] F. J. Humphreys and M. Hatherly, Recrystallization and Related Annealing Phenomena, Elsevier, Oxford, UK, 2004.

[11] E. Paul, J. T. Black, and R. A. Kohser, Materials and Processes in Manufacturing, John Wiley \& Sons, Hoboken, NJ, USA, 2003.

[12] R. E. Sanders Jr., "Technology innovation in aluminum products," The Journal of Minerals, vol. 53, no. 2, pp. 21-25, 2001.

[13] T. R. Ramachandran, "Advances in Aluminium Processing and Its Automotive Application," Workshop Lecture Notes, pp. 4144, Indian Institute of Metals, Pune Chapter, 2006.

[14] A. L. Dons, "The Alstruc homogenization model for industrial aluminum alloys," Journal of Light Metals, vol. 1, no. 2, pp. 133-148, 2001.

[15] O. Engler and J. Hirsch, "Texture control by thermomechanical processing of AA6xxx Al-Mg-Si sheet alloys for automotive applications - a review," Materials Science and Engineering A, vol. 336, no. 1-2, pp. 250-262, 2002.

[16] N. C. W. Kuijpers, W. H. Kool, P. T. G. Koenis, K. E. Nilsen, I. Todd, and S. van der Zwaag, "Assessment of different techniques for quantification of $\alpha-\mathrm{Al}(\mathrm{FeMn}) \mathrm{Si}$ and $\beta$-AlFeSi intermetallics in AA 6xxx alloys," Materials Characterization, vol. 49, no. 5, pp. 409-420, 2002.

[17] N. C. W. Kuijpers, J. Tirel, D. N. Hanlon, and S. van der Zwaag, "Quantification of the evolution of the 3D intermetallic structure in a 6005A aluminium alloy during a homogenisation treatment," Materials Characterization, vol. 48, no. 5, pp. 379392, 2002.

[18] S. N. Samaras and G. N. Haidemenopoulos, "Modelling of microsegregation and homogenization of 6061 extrudable Alalloy," Journal of Materials Processing Technology, vol. 194, no. 1-3, pp. 63-73, 2007.

[19] R. Vissers, M. A. van Huis, J. Jansen, H. W. Zandbergen, C. D. Marioara, and S. J. Andersen, "The crystal structure of the $\beta^{\prime}$ phase in Al-Mg-Si alloys," Acta Materialia, vol. 55, no. 11, pp. 3815-3823, 2007.

[20] N. C. W. Kuijpers, F. J. Vermolen, C. Vuik, P. T. G. Koenis, K. E. Nilsen, and S. van der Zwaag, "The dependence of the $\beta$-AlFeSi to $\alpha-\mathrm{Al}(\mathrm{FeMn}) \mathrm{Si}$ transformation kinetics in $\mathrm{Al}-\mathrm{Mg}-\mathrm{Si}$ alloys on the alloying elements," Materials Science and Engineering A, vol. 394, no. 1-2, pp. 9-19, 2005.

[21] Z. Ahmad, "The properties and application of scandiumreinforced aluminum," JOM, vol. 55, no. 2, pp. 35-39, 2003. 
[22] D. Kuhlmann-Wilsdorf, "Theory of plastic deformation," Materials Science and Engineering A, vol. 113, pp. 1-42, 1989.

[23] M. Schikorra, L. Donati, L. Tomesani, and A. E. Tekkaya, "Microstructure analysis of aluminum extrusion: prediction of microstructure on AA6060 alloy," Journal of Materials Processing Technology, vol. 201, no. 1-3, pp. 156-162, 2008.

[24] R. Lapovok, I. Timokhina, P. W. J. McKenzie, and R. O'Donnell, "Processing and properties of ultrafine-grain aluminium alloy 6111 sheet," Journal of Materials Processing Technology, vol. 200, no. 1-3, pp. 441-450, 2008.

[25] P. Mukhopadhyay, M. Loeck, and G. Gottstein, "A cellular operator model for the simulation of static recrystallization," Acta Materialia, vol. 55, no. 2, pp. 551-564, 2007.

[26] P. Mukhopadhyay and I. Samajdar, "Sources of recrystallized grains and their contributions in recrystallization of an AA3104 aluminium alloy," Transactions of the Indian Institute of Metals, vol. 61, no. 4, pp. 329-339, 2008.

[27] P. Mukhopadhyay, S. Biswas, and H. A. Chokshi, "Deformation characterization of superplastic AA7475 alloy," Transactions of the Indian Institute of Metals, vol. 62, no. 2, pp. 149 $152,2009$.

[28] P. Mukhopadhyay, "Modelling concurrent static recovery of aluminium alloy during recrystallization in cellular operator model," Aluminium, vol. 82, article 91, 2006.

[29] M. Goerdeler, M. Crumbach, P. Mukhopadhyay, G. Gottstein, L. Neumann, and R. Kopp, "Modelling the evolution of texture, microstructure and mechanical properties during hot rolling, cold rolling and annealing of VIR [*] AA5182," Aluminium, vol. 80, article 666, 2004.

[30] P. Mukhopadhyay, "Simulation of recrystallization texture of AA5182 and AA3104 with experimental validation," Aluminium, vol. 78, article 912, 2002.

[31] L. P. Troeger and E. A. Starke Jr., "Particle-stimulated nucleation of recrystallization for grain-size control and superplasticity in an Al-Mg-Si-Cu alloy," Materials Science and Engineering A, vol. 293, no. 1, pp. 19-29, 2000.

[32] W.-S. Lee, J.-C. Shyu, and S.-T. Chiou, "Effect of strain rate on impact response and dislocation substructure of 6061-T6 aluminum alloy," Scripta Materialia, vol. 42, no. 1, pp. 51-56, 2000.

[33] Abstract of Japanese Patent Publication no. 05 263203, Patent Abstract of Japan, 1993.

[34] Abstract of Japanese Patent Publication no. 63 109146, Patent Abstracts of Japan, 1988.

[35] Alloy and Temper Designation Systems for Aluminum and Aluminum Alloys, vol. 2, Metals Handbook, 10th edition, 1990.

[36] S . H. Avner, Introduction to Physical Metallurgy, TATA McGraw Hill, New Delhi, India, 2001.

[37] S. Esmaeili and D. J. Lloyd, "Modeling of precipitation hardening in pre-aged $\mathrm{AlMgSi}(\mathrm{Cu})$ alloys," Acta Materialia, vol. 53, no. 20, pp. 5257-5271, 2005.

[38] D. J. Chakrabarti and D. E. Laughlin, "Phase relations and precipitation in $\mathrm{Al}-\mathrm{Mg}-\mathrm{Si}$ alloys with $\mathrm{Cu}$ additions," Progress in Materials Science, vol. 49, no. 3-4, pp. 389-410, 2004.

[39] S. J. Andersen, H. W. Zandbergen, J. Jansen, C. Træholt, U. Tundal, and O. Reiso, "The crystal structure of the $\beta^{\text {" phase }}$ in Al-Mg-Si alloys," Acta Materialia, vol. 46, no. 9, pp. 32833298, 1998.

[40] B. Chalmers, Proceedings of the Royal Society A, vol. 193, p. 89, 1948.

[41] R. Clark and B. Chalmers, "Mechanical deformation of aluminium bicrystals," Acta Metallurgica, vol. 2, no. 1, pp. 80-86, 1954.
[42] G. J. Taylor, "Plastic strain in metals," Japan Institute of Metals, vol. 62 , p. 307, 1938.

[43] J. F. W. Bishop and R. Hill, "XLVI. A theory of the plastic distortion of a polycrystalline aggregate under combined stresses," Philosophical Magazine, vol. 42, pp. 414-427, 1951.

[44] J. F. W. Bishop and R. Hill, " CXXVIII. A theoretical derivation of the plastic properties of a polycrystalline face-centred meta," Philosophical Magazine, vol. 42, pp. 1298-1307, 1941.

[45] U. F. Kocks, "Polyslip in polycrystals," Acta Metallurgica, vol. 6, no. 2, pp. 85-94, 1958.

[46] U. F. Kocks, "The relation between polycrystal deformation and single-crystal deformation," Metallurgical and Materials Transactions, vol. 1, no. 5, pp. 1121-1143, 1970.

[47] E. O. Hall, "The deformation and ageing of mild steel: III discussion of results," Proceedings of the Physical Society B, vol. 64, no. 9, pp. 747-753, 1951.

[48] N. J. Petch, "The cleavage strength of polycrystals," Journal of the Iron and Steel Institute London, vol. 173, pp. 25-28, 1953.

[49] N. Hansen and B. Ralph, "The strain and grain size dependence of the flow stress of copper," Acta Metallurgica, vol. 30, no. 2, pp. 411-417, 1982.

[50] P. K. Sharma and T. R. Ramachandran, An Update on Grain Refinement of Aluminium Alloys, Workshop Lecture Notes, Indian Institute of Metals, Pune Chapter, 2006.

[51] A. Cibula, "The mechanism of grain refinement of sand castings in aluminum alloys," The Journal of the Institute of Metals, vol. 786, pp. 321-360, 1950.

[52] M. Easton and D. St John, "Grain refinement of aluminum alloys: part I. The nucleant and solute paradigms-a review of the literature," Metallurgical and Materials Transactions A, vol. 30, no. 6, pp. 1613-1623, 1999.

[53] M. Easton and D. St John, "Grain refinement of aluminum alloys: part II. Confirmation of, and a mechanism for, the solute paradigm," Metallurgical and Materials Transactions A, vol. 30, no. 6, pp. 1625-1633, 1999.

[54] M. Easton and D. St John, "Grain refinement of aluminum alloys: part I. The nucleant and solute paradigms-a review of the literature," Metallurgical and Materials Transactions A, vol. 30, no. 6, pp. 1613-1623, 1999.

[55] T. R. Ramachandran, Trace Elements in Aluminium and Aluminium Alloys, Workshop Lecture Notes, Indian Institute of Metals, Pune Chapter, 2006.

[56] J. W. Martin, Precipitation Hardening, Pergamon Press, New York, NY, USA, 1968.

[57] E. Orowan, Symposium on Internal Stresses, Institute of Metals, London, UK, 1947.

[58] A. Kelly, "Precipitation hardening," Progress in Materials Science, vol. 10, no. 3, pp. 151-391, 1963.

[59] H. Gleiter and E. Hornbogen, "Precipitation hardening by coherent particles," Materials Science and Engineering, vol. 2, no. 6, pp. 285-302, 1967.

[60] N. F. Mott and F. R. N. Nabarro, "An attempt to estimate the degree of precipitation hardening with a simple model," Proceedings of the Physics Society London, vol. 52, article 86, 1940.

[61] V. Gerold and H. Haberkorn, "On the critical resolved shear stress of solid solutions containing coherent precipitates," Physica Status Solidi, vol. 16, no. 2, pp. 675-684, 1966.

[62] P. B. Hirsch and A. Kelly, "Stacking-fault strengthening," Philosophical Magazine, vol. 12, no. 119, pp. 881-900, 1965.

[63] L. M. Brown and R. K. Hamm, in Strengthening Methods in Crystals, A. Kelly and R. B. Nicholson, Eds., p. 10, Elsevier, London, UK, 1971. 
[64] D. McLean, Mechanical Properties of Metals, John Wiley \& Sons, New York, NY, USA, 1962.

[65] M. A. Meyers and K. K. Chawla, Mechanical Metallurgy, Prentice Hall, Englewood Cliffs, NJ, USA, 1984.

[66] F. Roters, D. Raabe, and G. Gottstein, "Work hardening in heterogeneous alloys," Acta Materialia, vol. 48, no. 17, pp. 4181$4188,2000$.

[67] H. Conrad, "Thermally activated deformation of metals," Journal of Metals, vol. 145, no. 3638, pp. 582-588, 1964.

[68] A. Seeger, Dislocations and Mechanical Properties of Crystals, John Wiley \& Sons, New York, NY, USA, 1957.

[69] R. P. Garrett, J. Lin, and T. A. Dean, "An investigation of the effects of solution heat treatment on mechanical properties for AA 6xxx alloys: experimentation and modelling," International Journal of Plasticity, vol. 21, no. 8, pp. 1640-1657, 2005.

[70] L. P. Troeger and E. A. Starke Jr., "Microstructural and mechanical characterization of a superplastic 6xxx aluminum alloy," Materials Science and Engineering A, vol. 277, no. 1-2, pp. 102-113, 2000.

[71] T. R. Ramachandran, P. K. Sharma, and K. Balasubramanian, Aluminium for Automotive Applications, Workshop Lecture Notes, Indian Institute of Metals, Pune Chapter, 2006.

[72] Proceeding of Automotive Committee, The Japan Aluminium Association, 2002.

[73] J. Hirsch, Automotive Trends in Aluminium, The European Perspective, Workshop Lecture Notes, Indian Institute of Metals, Pune Chapter, 2006.

[74] T. Sheppard, Extrusion of Aluminium Alloys, Kluwer Academic, Dodrecht, The Netherlands, 1999.

[75] G. B. Burger, A. K. Gupta, P. W. Jeffrey, and D. J. Lloyd, "Microstructural control of aluminum sheet used in automotive applications," Materials Characterization, vol. 35, no. 1, pp. 23-39, 1995. 

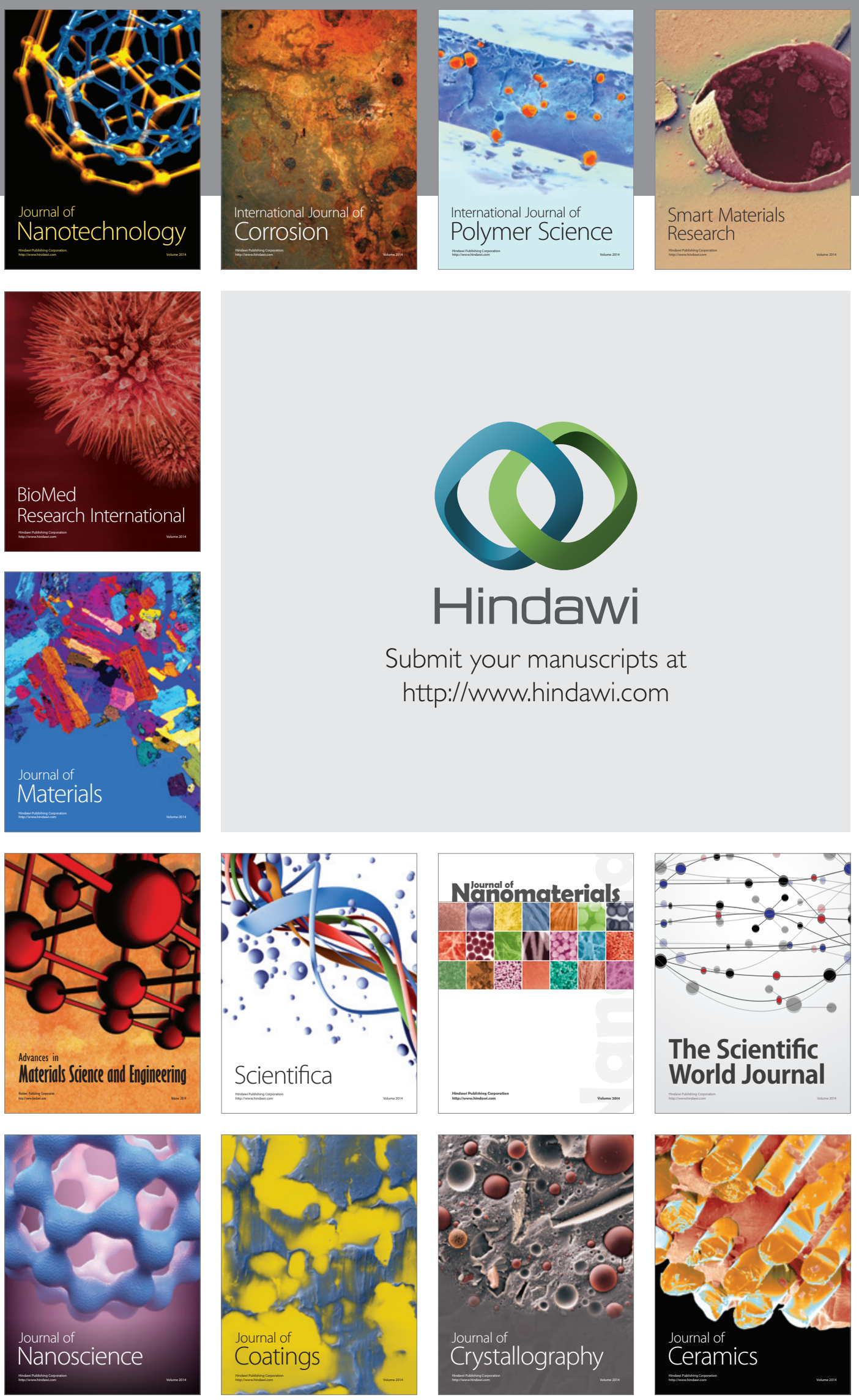

The Scientific World Journal

Submit your manuscripts at

http://www.hindawi.com

\section{World Journal}

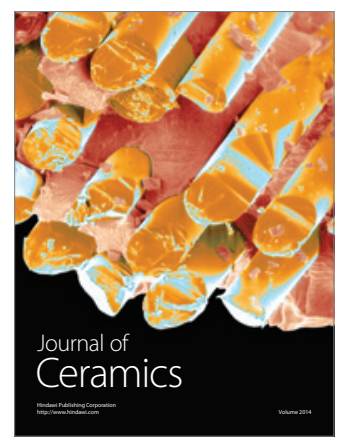

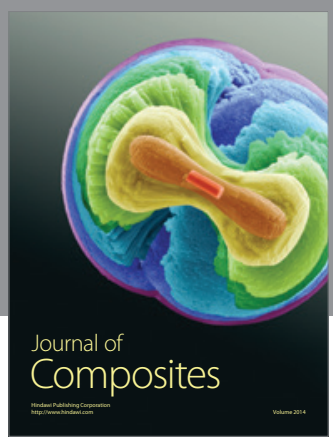
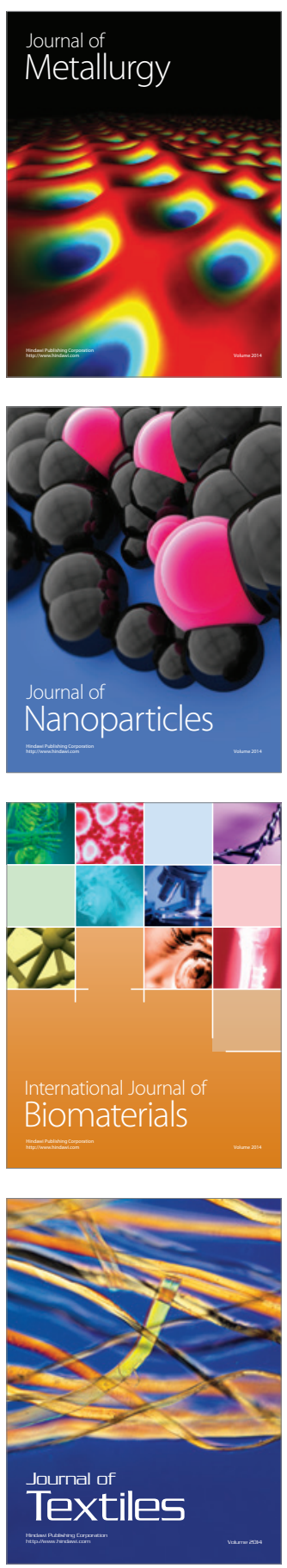